\title{
A Holistic Approach to Develop IS Curricula: Focusing on Accreditation and IT Certification
}

\author{
Akram Al-Rawi, Azzedine Lansari, and Faouzi Bouslama \\ College of Information Systems, Zayed University \\ Abu Dhabi, UAE
}

\author{
akram.alrawi@zu.ac.ae azzedine.lansari@zu.ac.ae \\ faouzi.bouslama@zu.ac.ae \\ Executive Summary
}

Academic institutions worldwide are constantly trying to refine or even reinvent their Information Systems (IS) curricula to address the needs of industry and government. As many IS curricula emerge, a number of them do not satisfy well recognized standards and even lack critical components. Furthermore, a highly competitive Information Technology (IT) global market is putting pressure on colleges and universities to include IT certification in the curriculum.

The goal of this paper is to propose a comprehensive model IS curriculum based on well recognized standards while integrating the objectives of key IT certificates. ABET (Accreditation Board for Engineering and Technology) is the main agency for accrediting IS programs in the U.S. The ABET criteria, which specify the requirements for designing IS curricular components, are used to design the model curriculum. These components consist of general education courses, environmental courses, major core courses, major electives and general elective courses. Furthermore, the IS 2002 report, which identifies specific features of the IS profession and shows how to integrate them into IS curricula, is used to implement the ABET core courses. The IS 2002 report is studied in order to develop the core IS component of the proposed model curriculum. In addition, key IT certifications as well as IS components that have the potential to lead to these IT certifications are identified.

In this study, four areas in the IS model curriculum are identified to integrate IT certification objectives. These areas are: Personal productivity, Networking, Programming and problem solving, and Hardware and software. Five IT certificates that can be integrated in these four areas are identified. These are: MS MOUS or ECDL, CompTIA Network +, Cisco CCNA, CompTIA A+, and Sun Certified Programmer for Java 2 Platform. An example showing how to integrate Network + certification, Cisco CCNA, is presented with a comparison between Cisco CCNA and CompTIA Network + . A master course syllabus that covers the CCNA objectives is developed. It is anticipated that colleges and universities will benefit from this study by using the proposed IS

model curriculum as a framework for

Material published as part of this journal, either on-line or in print, is copyrighted by the publisher of the Journal of Information Technology Education. Permission to make digital or paper copy of part or all of these works for personal or classroom use is granted without fee provided that the copies are not made or distributed for profit or commercial advantage AND that copies 1) bear this notice in full and 2) give the full citation on the first page. It is permissible to abstract these works so long as credit is given. To copy in all other cases or to republish or to post on a server or to redistribute to lists requires specific permission and payment of a fee. Contact Editor@JITE.org to request redistribution permission. easy integration of certification modules into IS courses.

Keywords: Information Systems, ABET, IS 2002, Curricula, Accreditation, Certification. 


\section{Introduction}

Information Systems (IS) are complex systems requiring both technical and organizational expertise for design, development, and management. Many academic institutions worldwide aim to generate an IS curriculum that produces graduates with solid foundation in IS and equipped with the skills that make them readily employable. However, all aspects of the computing fields including IS are faced with great pressure from industry to train students on specific IT technology and skills. As a result, university level IS curricula need frequent updating to answer the need of industry and to remain effective. The highly competitive Information Systems field requires universities and colleges to train students on the use of the latest technologies. Some academic institutions are redesigning their curricula to include IT certifications into their curricula. This process provides graduates with a solid foundation in IS and one or more IT certificate. Businesses today need college graduates to make an impact and become productive employees almost immediately after joining the work force.

Information Systems (IS) programs are accredited by oversight bodies to determine whether the program provides quality education (Lidtke \& Yaverbaum, 2003; Lunt, Lawson, Goodman, \& Helps, 2002). Currently, ABET (Computing Accreditation Commission, 2004) is the accreditation body with responsibility for accrediting all programs in the computing field. The Computing Accreditation Commission (CAC) is responsible for the accreditation of IS programs. The IS 2002 model curriculum provides recommendation for the core IS curriculum to meet ABET criteria. While ABET specifies the 120 credit hours for the Bachelor degree, IS 2002 addresses 33 credit hours only.

Currently, there is a move by a number of colleges and universities to form partnership with IT vendors such as Microsoft and Cisco to provide hands-on experience that prepares students for successful entry into the job market and to sit for Industry Certification exams (Houston, Blesse, $\&$ Herrod, 2005). Many employers are looking for IS graduates to acquire certification in addition to their Bachelor degree. IS graduates can demonstrate that they have the necessary skills to be productive by acquiring one or more appropriate IT certificates. The IEEE and ACM recognize the importance of the IT certifications and provide their members with over four hundred online courses leading to technical certifications.

In this paper, an IS model curriculum that addresses accreditation requirements and certification needs is proposed. The model addresses all ABET criteria, which provide recommendations for general education (GE), IS environment, major core courses, major electives and general elective courses. The model curriculum uses the IS 2002 report (Gorgone, Davis, Valacich, Topi, Feinstein, \& Longenecker, 2002) to implement the IS core courses. The model also provides a framework to integrate IT certification in IS courses at various levels of the curriculum. $\mathrm{n}$ example of how to use the proposed model curriculum is developed. The rest of the paper is organized as follows. The second section lists the criteria for accrediting IS programs. The third section introduces the IS 2002 recommendations for curriculum development and addresses some of the implementations issues. The fourth section discusses the proposed comprehensive IS curriculum. The fifth and sixth sections discuss embedding IT certification into the IS curriculum. The seventh section presents an example of how to implement the model curriculum. Finally the eighth section is the conclusion.

\section{ABET Criteria for Accrediting IS Programs}

ABET, a recognized accreditor for college and university programs in applied science, computing, engineering, and technology, is a federation of 30 professional and technical societies representing these fields. Among the most respected accreditation organizations in the U.S., ABET has 
provided leadership and quality assurance in higher education for over 70 years. ABET also offer educational credentials evaluation services outside the U.S.

There are many competing IS programs in the US and worldwide (Reichgelt, Lunt, Ashford, Phelps, Slazinski, \& Willis, 2004). The driving forces for these programs are different. Therefore, the emphasis of each IS program varies widely. There are many benefits for having an accredited IS program. The main reason for having an accredited IS program is to meet international standards and abilities. An accredited program has the ability to adapt to emerging technologies and changing disciplines and provide a framework to keep programs current, relevant and educationally sound. Currently, ABET (Computing Accreditation Commission, 2004) is the only agency with responsibility for accrediting all programs in computing, engineering, and technology in the US. Recently, ABET requirement covers eight areas; these are: Objectives and Assessments; Students; Faculty; Curriculum; Technology Infrastructure; Institutional Support and Financial Resources; Program Delivery; and Institutional Facilities.

The focus of this paper is on the curriculum component of the ABET requirements. Table 1 provides a description of the curriculum intent, standards, and components (Computing Accreditation Commission, 2004). The other seven ABET requirements will not be addressed in this paper.

\begin{tabular}{|c|c|}
\hline \multicolumn{2}{|r|}{ Table 1: ABET curriculum requirements } \\
\hline CRITERIA & DESCRIPTION \\
\hline Intent & $\begin{array}{l}\text { The curriculum combines professional requirements with general education require- } \\
\text { ments and electives to prepare students for a professional career in the IS field, for fur- } \\
\text { ther study in IS, and for functioning in modern society. The professional requirements } \\
\text { include coverage of basic and advanced topics in IS as well as an emphasis on an IS } \\
\text { environment. }\end{array}$ \\
\hline Standards & $\begin{array}{l}\text { Curriculum standards are specified in terms of semester-hours of study. Thirty semester- } \\
\text { hours generally constitutes one year of full-time study. A course or a specific part of a } \\
\text { course can only be applied toward one standard. }\end{array}$ \\
\hline General & $\begin{array}{l}\text { - The curriculum must include at least } 30 \text { semester-hours of study in IS topics. } \\
\text { - The curriculum must contain at least } 15 \text { semester-hours of study in IS environment, } \\
\text { such as business or education. } \\
\text { - The curriculum must include at least } 9 \text { semester-hours of study in quantitative } \\
\text { analysis. } \\
\text { - The curriculum must include at least } 30 \text { semester-hours of study in general educa- } \\
\text { tion to broaden the background of the student. }\end{array}$ \\
\hline $\begin{array}{l}\text { Information } \\
\text { Systems }\end{array}$ & $\begin{array}{l}\text { - All students must take a broad-based core of fundamental IS material consisting of } \\
\text { at least } 12 \text { semester hours. } \\
\text { - The core materials must provide basic coverage of the hardware and software, a } \\
\text { modern programming language, data management, networking and telecommunica- } \\
\text { tions, analysis and design, and the role of IS in organizations. } \\
\text { - Theoretical foundations, analysis, and design must be stressed throughout the pro- } \\
\text { gram. } \\
\text { - Students must be exposed to a variety of information and computing systems and } \\
\text { must become proficient in one modern programming language. } \\
\text { - All students must take at least } 12 \text { semester hours of advanced course work in IS } \\
\text { that provides breadth and builds on the IS core to provide depth. }\end{array}$ \\
\hline IS Environment & $\begin{array}{l}\text { The } 15 \text { semester hours must be a cohesive body of knowledge to prepare the stu- } \\
\text { dents to function effectively as an IS professional in the IS environment }\end{array}$ \\
\hline
\end{tabular}




\begin{tabular}{|l|l|}
\hline $\begin{array}{l}\text { Quantitative } \\
\text { Analysis }\end{array}$ & $\begin{array}{l}\text { - The curriculum must include at least } 9 \text { semester-hours of quantitative analysis be- } \\
\text { yond pre-calculus. }\end{array}$ \\
\hline $\begin{array}{l}\text { Additional Ar- } \\
\text { - Calculics must be included. }\end{array}$ \\
eas of Study & $\begin{array}{l}\text { - The oral and written communications skills of the student must be developed and } \\
\text { applied in the program. }\end{array}$ \\
& $\begin{array}{l}\text { There must be sufficient coverage of global, economic, social and ethical implica- } \\
\text { tions of computing to give students an understanding of a broad range of issues in } \\
\text { these areas. }\end{array}$ \\
& Collaborative skills must be developed and applied in the program. \\
\hline
\end{tabular}

ABET provides general guidelines for the IS curriculum. However, the implementation of their requirement varies from one institution to another. The IS 2002 report (Gorgone, et al., 2002) is the latest output from model curriculum work for implementing the 30 semester-hours of study in IS topics. The report has been developed by the Association for Computing Machinery (ACM), Association for Information Systems (AIS), and Association for Information Technology Professionals (AITP). IS 2002 has been widely accepted and has become the basis for accreditation of undergraduate programs in IS. The report represents the combined effort of numerous individuals and reflects the interest of thousands of faculties. The summary of the IS 2002 model is discussed in the next section.

\section{IS 2002 Model Curriculum}

Most academic units have mechanisms to maintain currency of curricula (Denning, 2001; Mehic \& Al-Soufi, 1999). However, the availability of curriculum models should enable local academic units to maintain academic programs that are consistent both with regional and national employment needs while keeping the common body of knowledge of the IS field.

IS 2002 report identifies four characteristics of the IS profession and integrates them into their model curriculum. These are:

- IS professionals must have a broad business and real world perspective.

- IS professionals must have strong analytical and critical thinking skills.

- IS professionals must have interpersonal communication and team skills and have strong ethical principles.

- IS professional must design and implement IT solutions that enhance organizational performance.

The model curriculum includes 30 credit hours of formal IS courses and also assumes the use of prerequisite or co-requisite courses in communications, mathematics and statistics, and business functions. The communications prerequisite courses should provide students with listening skills and the knowledge to be effective in written and oral communication. The mathematics and statistics prerequisites should provide basic quantitative and qualitative techniques. The business courses should cover common business functions, economics, and international considerations. The IS 2002 report recommends an embedded problem solving and critical thinking framework in all courses.

The architecture of the IS curriculum consists of five curriculum presentation areas: IS fundamentals; IS theory and practice; information technology; IS development; and IS deployment and management processes. The five presentation areas consist of ten courses and one prerequisite course as shown in Table 2. 
Table 2. IS 2002 model curriculum

\begin{tabular}{|c|c|c|}
\hline COURSE \# & COURSE NAME & SCOPE \\
\hline IS 2002.P0 & $\begin{array}{l}\text { Personal Productivity } \\
\text { with IS Technology }\end{array}$ & $\begin{array}{l}\text { This prerequisite course enables students to improve their skills } \\
\text { as knowledge workers. The emphasis is on personal productiv- } \\
\text { ity concepts using functions and features in computer software } \\
\text { such as spreadsheets, databases, presentation graphics, and Web } \\
\text { authoring. Although identified as a course, this material can be } \\
\text { delivered as self-study modules, as modules associated with } \\
\text { other courses using the software, or as a full course. }\end{array}$ \\
\hline IS 2002.1 & $\begin{array}{l}\text { Fundamentals of In- } \\
\text { formation Systems }\end{array}$ & $\begin{array}{l}\text { This course provides an introduction to systems and develop- } \\
\text { ment concepts, information technology, and application soft- } \\
\text { ware. It explains how information is used in organizations and } \\
\text { how IT enables improvement in quality, timeliness, and com- } \\
\text { petitive advantage. }\end{array}$ \\
\hline IS 2002.2 & $\begin{array}{l}\text { Electronic Business } \\
\text { Strategy, Architecture } \\
\text { and Design }\end{array}$ & $\begin{array}{l}\text { This course examines the linkage of organizational strategy and } \\
\text { electronic methods of delivering products, services and ex- } \\
\text { changes in inter-organizational, national, and global environ- } \\
\text { ments. Information technology strategy and technological solu- } \\
\text { tions for enabling effective business processes within and be- } \\
\text { tween organizations in a global environment are considered. }\end{array}$ \\
\hline IS 2002.3 & $\begin{array}{l}\text { Information Systems } \\
\text { Theory and Practice }\end{array}$ & $\begin{array}{l}\text { This course provides an understanding of organizational sys- } \\
\text { tems, planning, and decision process, and how information is } \\
\text { used for decision support in organizations. It covers quality and } \\
\text { decision theory, information theory, and practice essential for } \\
\text { providing viable information to the organization. It outlines the } \\
\text { concepts of IS for competitive advantage, data as a resource, IS } \\
\text { and IT planning and implementation, change, and project man- } \\
\text { agement. }\end{array}$ \\
\hline IS 2002.4 & $\begin{array}{l}\text { Information Technol- } \\
\text { ogy Hardware and Sys- } \\
\text { tem Software }\end{array}$ & $\begin{array}{l}\text { This course provides the hardware/software technology back- } \\
\text { ground to enable systems development personnel to understand } \\
\text { tradeoffs in computer architecture for effective use in a business } \\
\text { environment. System architecture for networked computing } \\
\text { systems and operating systems will be covered. }\end{array}$ \\
\hline IS 2002.5 & $\begin{array}{l}\text { Programming, Data, } \\
\text { File and Object Struc- } \\
\text { tures }\end{array}$ & $\begin{array}{l}\text { This course provides an exposure to algorithm development, } \\
\text { programming, computer concepts, and the design and applica- } \\
\text { tion of data and file structures. It includes the use of logical and } \\
\text { physical structures for both programs and data. }\end{array}$ \\
\hline IS 2002.6 & $\begin{array}{l}\text { Networks and Tele- } \\
\text { communication }\end{array}$ & $\begin{array}{l}\text { This course provides an in-depth knowledge of data communi- } \\
\text { cations and networking requirements including networking and } \\
\text { telecommunications technologies, hardware, and software. Em- } \\
\text { phasis is upon the analysis and design of networking applica- } \\
\text { tions in organizations. Management of telecommunications } \\
\text { networks, cost-benefit analysis, and evaluation of connectivity } \\
\text { options are covered. Students learn to evaluate, select, and im- } \\
\text { plement different communication options within an organiza- } \\
\text { tion. }\end{array}$ \\
\hline
\end{tabular}




\begin{tabular}{|l|l|l|}
\hline IS 2002.7 & $\begin{array}{l}\text { Analysis and Logical } \\
\text { Design }\end{array}$ & $\begin{array}{l}\text { This course examines the system development and modification } \\
\text { process. It emphasizes the factors for effective communication } \\
\text { and integration with users and user systems. It encourages in- } \\
\text { terpersonal skill development with clients, users, team mem- } \\
\text { bers, and others associated with development, operation, and } \\
\text { maintenance of the system. Structured and object oriented } \\
\text { analysis and design, use of modeling tools, adherence to meth- } \\
\text { odological life cycle and project management standards. }\end{array}$ \\
\hline IS 2002.8 & $\begin{array}{l}\text { Physical Design and } \\
\text { Implementation with } \\
\text { DBMS }\end{array}$ & $\begin{array}{l}\text { This course covers information systems design and implementa- } \\
\text { tion within a database management system environment. Stu- } \\
\text { dents will demonstrate their mastery of the design process ac- } \\
\text { quired in earlier courses by designing and constructing a physi- } \\
\text { cal system using database software to implement the logical } \\
\text { design. }\end{array}$ \\
\hline IS 2002.9 & $\begin{array}{l}\text { Physical Design and } \\
\text { Implementation in } \\
\text { Emerging Environ- } \\
\text { ments }\end{array}$ & $\begin{array}{l}\text { This course covers physical design and implementation of in- } \\
\text { formation systems applications. Implementation in emerging } \\
\text { distributed computing environments using traditional and con- } \\
\text { temporary development methodologies. }\end{array}$ \\
\hline IS 2002.10 & $\begin{array}{l}\text { Project Management } \\
\text { and Practice }\end{array}$ & $\begin{array}{l}\text { This course covers the factors necessary for successful man- } \\
\text { agement of information systems development or enhancement } \\
\text { projects. Both technical and behavioral aspects of project man- } \\
\text { agement are applied within the context of an information sys- } \\
\text { tems development project. }\end{array}$ \\
\hline
\end{tabular}

There are a number of issues in implementing the IS 2002 model. One of these issues is the selection of an appropriate modern programming language that fulfills the requirements of the ABET criteria as well as the IS 2002 recommendations. ABET requires the student to be proficient in a modern programming language, however, the IS 2002 recommendations include only one course in programming. To become proficient in a modern programming language, students must take at least two courses in programming.

As to the selection of the programming language, Java, a modern object-oriented language, can be used to satisfy ABET requirement. In fact many universities are using Java as the primary programming language (Benander, Benander, \& Sang, 2004). However, other languages such as $\mathrm{C}++, \mathrm{CH}$, or VB.NET can also be used.

Another issue is that even though the IS 2002 model provides course descriptions, some of the course material cannot be found in a single textbook. For example, the IT hardware and software systems course requires the use of several uncorrelated textbooks. For this reason, it is very common to find an IS curriculum that does not include all the ten IS 2002 model courses.

\section{Proposed IS Curriculum}

The proposed model curriculum for the IS major consists of six components: General education, IS core courses, IS electives, General electives, IS environment, and Quantitative analysis. These six areas are chosen to fulfill ABET requirements. Details of each of the six components of the IS model curriculum are given in the following subsections.

\section{General Education (39 credits)}

General education (GE) is an essential part of every student's program of study. GE explores and promotes understanding of the interrelationship among the liberal arts and sciences including the arts, history, humanities, mathematics, and the natural, social and behavioral, and computer liter- 
acy. GE provides a foundation for the student to pursue lifelong learning and involved citizenship. These studies broaden and deepen understanding of the world through free and critical inquiry. GE encourages creativity and the discovery, acquisition and application of knowledge in the pursuit of excellence.

In most U.S. academic institutions, the required GE credit hours vary from 34 to 47 depending on the institution's goals and objectives. ABET criteria for accreditation require minimum of 30 credit hours of GE. In this model we have recommended 39 semester hours of GE, which includes three areas: basic studies, introductory studies, and ethics. This recommendation is based on the requirements of most liberal art colleges in the US.

\section{Basic studies (12 credits)}

Basic studies courses serve the student by supplying critical thinking skills, knowledge and techniques that enhance and enrich subsequent coursework. These courses are:

- Introduction to Computer Information Systems (3)

- Introduction to Speech (3)

- English Composition II (3)

- College Algebra or Statistics I or Calculus and Analytic Geometry (3)

\section{Introductory studies (24 credits)}

Introductory studies provide the student with a varied and rich learning experience that is the essence of a liberal arts and science education. These courses provide a foundation for advanced studies regardless of major. Students must select courses, with a minimum of 6 semester hours, from each of the following areas:

- Arts and Humanities (6)

- Art Appreciation

- Communication (recommended for IS students)

- Language

- Literature

- Philosophy (recommended for IS students)

- Religious studies

- Natural Sciences and Mathematics (9)

- Astronomy

- Biology

- Chemistry

- Geology

- Mathematics (recommended for IS students)

- Statistics (recommended for IS students)

- Physics

- Social and Behavioral Sciences (9)

- Economics (micro and macro, recommended for IS students)

- Geography

- Political Science

- Psychology

- Sociology

\section{Ethics ( 3 credits)}

Every student must complete an ethics course; it could be either a course in philosophy or an approved college ethics course. 
Although students have a wide range of courses to choose from to fulfill the general education requirements, they should be advised to take the recommended courses as shown in the previous section.

\section{Information Systems Core Courses (33 credits)}

The IS model curriculum core materials must provide basic coverage of the IT hardware and software, a modern programming language, data management, networking and data communications, analysis and design, and the role of IS in organizations, as shown in Figure 1. The major core courses in the model curriculum use the IS 2002 model and consist of 33 credit hours that can be mapped into the following 11 courses.

- Personal Computer Productivity Tools (3)

- Introduction to Computer Information Systems (3)

- Web Programming (3)

- IT Hardware and Software (3)

- Object Oriented Programming (3)

- Advanced Object Oriented Programming (3)

- Networks and Data Communications (3)

- Systems Analysis and Design (3)

- Database Systems (3)

- Algorithms and Data Structures (3)

- Project Management (3)

The course "Introduction to CIS" is a general education course. In some institutions this course has a lab component, which includes parts of the Personal Computer Productivity Tools course. By making the course "Introduction to CIS" four credit hours, the Personal Computer Productivity Tools course can be easily integrated. As of today, there is no good textbook that can be used for the IT Hardware and Software course. The course description of the above IS courses are listed in many college catalogues. For clarity purposes, the description of the Object Oriented Programming and Web Programming courses are shown in Appendix A.

\section{Information Systems Environment (15 credits)}

ABET requires 15 semester hours to prepare the student to function effectively as an IS professional in the IS environments. The courses taken are to broaden the student's background in the area in which the IS knowledge is to be applied. For example, in the business environment, the student would take courses in the following areas: management, accounting, organizational behavior, marketing, finance, microeconomics, and macroeconomics. If the program is located in a business school, these courses are frequently specified by institutional requirements. To satisfy ABET requirements five courses are recommended as shown below. These fifteen hours fulfill ABET requirement for business environment. However, if the environment is education, for example, then student needs to select different courses.

- Financial Accounting (3)

- Principles of Economics I (Micro) (3), GE

- Principles of Economics II (Macro) (3), GE

- Financial Management (3)

- Organizational Behavior (3)

Some of the five courses can be taken to satisfy the GE requirements. However, credits will only be counted toward one particular area. For example if a student takes Principles of Economics I as part of a GE requirement, those credits cannot be counted toward the IS environments. Georgia 
Southern University (Reichgelt, Zhang, \& Price, 2002) requires additional 24 credit hours in the environment area in addition to the regular 120 credit hours.

\section{Quantitative Analysis (9 credits)}

To satisfy ABET requirements nine semester hours are recommended as shown below. However, one of the courses can also be taken to satisfy the general education requirements as discussed earlier.

- Statistics I (3), GE

- Discrete mathematics (3)

- Statistics II (3)

\section{Information Systems Electives (18 credits)}

Eighteen semester hours selected from the courses shown below are recommended. ABET specifies that all students must take at least 12 semester hours of advanced course work in IS that provides breadth and builds on the IS core to provide depth. IS electives varies from institution to institution depends on the demands of the local markets and the interest of students and faculty.

- Introduction to COBOL Programming

- Operating Systems

- Introduction to Visual Basic.NET Programming

- Object Oriented Analysis and Design

- Topics in Information Systems

- Computer Graphics

- Multimedia Systems

- Web Management

- Internship

- Computer Systems \& Assembly Language

- Computer Architecture \& Organization

- E-business \& E-commerce

- Capstone Experience

\section{General Electives (15 credits)}

These hours can be taken from the IS program or any other program, depending on the student interest. The total number of hours should be 126 to meet the graduation requirement. However, ABET requires a minimum of 120 semester hours only.

Figure 1 shows the sequence of courses for the proposed IS core curriculum. The complete list of recommended courses for the proposed IS model curriculum is shown in Appendix B. 


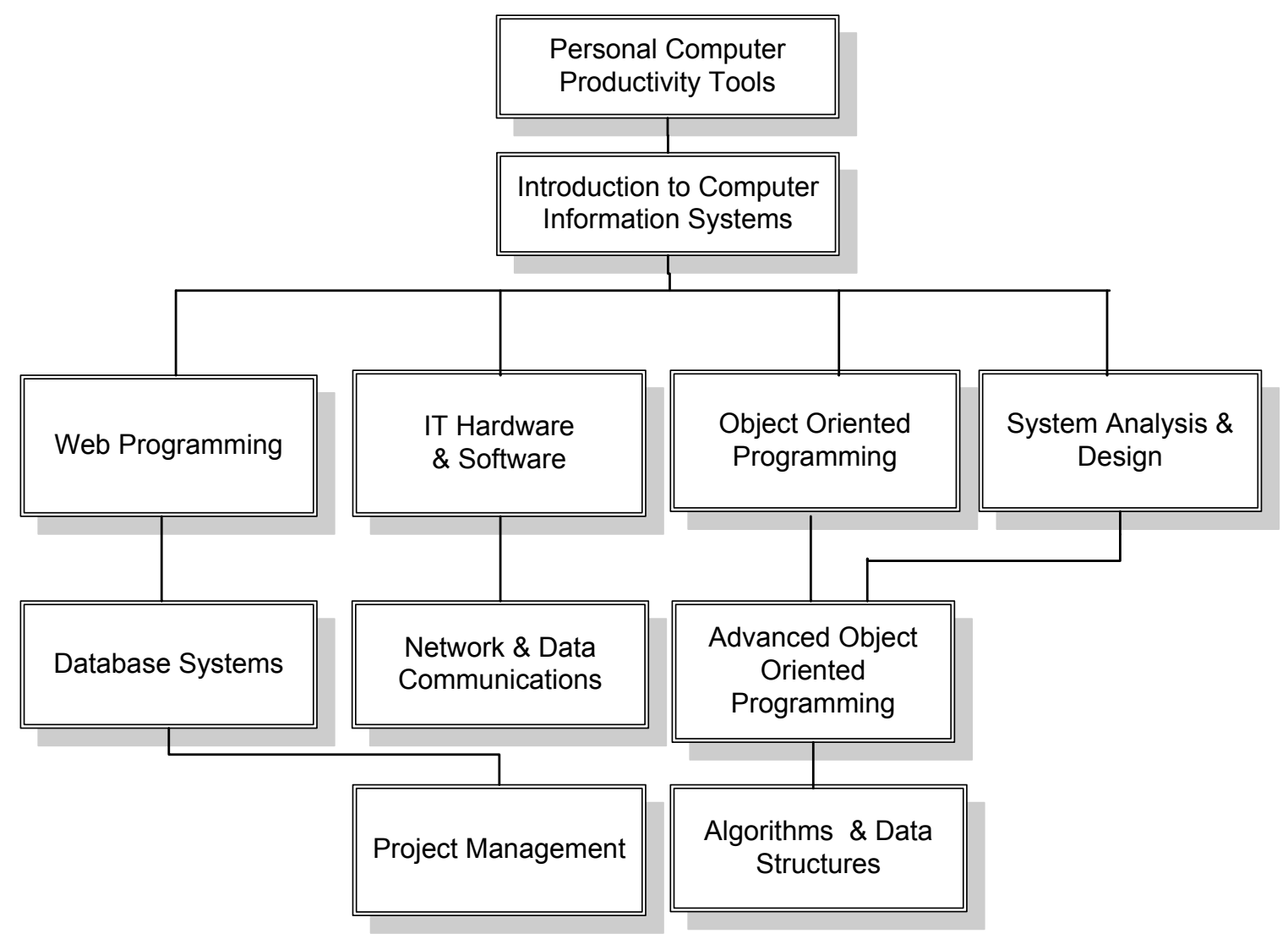

Figure 1: IS Core Model Curriculum

\section{IT Certifications}

IT certification is the process of mastering material pertaining to a particular hardware system, operating system, programming language, or other software program, and then proving mastery by passing a series of exams. Certification programs are developed and administered either by a manufacturer or a professional organization such as the Computing Technology Industry Association (CompTIA). Students can pursue a number of different certifications, depending on student specialty interest. For example to prove a mastery of many aspects of networking, student can choose to become Network + certified. Benefits for becoming certified may come in the form of:

- Additional knowledge and skills that allow individuals to move into a new area or perform current job more effectively.

- Exposure to the latest software, equipment or other knowledge.

- Increased level of expertise

- Contact and networking with top-performing professionals in the field, around the world.

- Customer confidence based on the evidence of qualifications.

The IEEE and ACM recognized the importance of certification and provide its members with over four hundred online courses leading to professional certifications, such as CompTIA Network + and Cisco CCNA. Each certificate has certain objectives. Moreover, ACM has developed a $\underline{\mathrm{K}-12}$ computer science curriculum which recommend including three IT certifications; the $\underline{\mathrm{A}+}$ Certified Technician, the iNET+, and the Certified Internet webmaster (Tucker, Deek, Jones, McCowan, Stephenson, \& Verno, 2003). The ACM report suggests that students who complete 
the certification courses should be encouraged to take the corresponding exam as proof of acquired knowledge.

There are many ways to acquire IT certification. Vendors such as Sun Microsystems and Microsoft offer training courses for their particular certification. There are also training institutions which offer courses for almost any certificate. Community colleges have designed their programs to concentrate on a specific field, such as network administration, PC technician, Help Desk technician and Customer Service Technician (Zeng, 2004). Currently, very few universities offer training which leads to IT certifications. Acquiring IT certification is becoming popular among university students and has resulted in some universities including some IT certifications into their curriculum.

\section{Integrating IT Certification into IS Courses}

All IT certifications have specific objectives and require mastering certain skills that are not necessarily included in IS curricula. On the other hand, IS courses have specific objectives and outcomes that need to be achieved in order to pass the course and fulfill the accreditation requirement. In this study, four areas in the IS curriculum that can be strengthened by IT certification have been identified. These are: personal productivity tools, networking, programming and problem solving, and hardware and software. Furthermore, five potential IT certificates that can be integrated in these areas have been identified, as shown in Table 3. These are: MS MOUS or ECDL, CompTIA Network+, Cisco CCNA, CompTIA A+, and Sun Certified Programmer for Java 2 platform.

The Microsoft Office User Specialist (MOUS) is an IT certificate that measures and validates skills in the MS Office suite. The MOUS certificate objectives can be easily integrated into the personal productivity with IS Technology course (IS 2002.P0), which is a prerequisite course in the IS 2002 model curriculum. IS 2002.P0 emphasizes personal productivity concepts using functions and features in computer software such as spreadsheets, databases, presentation graphics and web authoring. This course requires prior elementary knowledge of word processing, spreadsheet, email, and web browsing. The IS 2002.P0 objectives can integrate the objectives of the MOUS certificate which include the mastery of Microsoft Word, Excel, Access, PowerPoint, and Outlook. The MOUS offers various levels of expertise including: Master, Expert and Specialist. The master certification requires the candidates to successfully complete three required exams (Word 2002 Expert, Excel 2002 Expert, and PowerPoint 2002) and one elective exam (either Access 2002 or Outlook 2002).

The computing technology industry association (CompTIA) provides six certificates including the $\mathrm{A}+$ and the Network + . The $\mathrm{A}+$ is designed to provide a competency level for personal computer repair and maintenance technicians. The A+ certification insures that the IT professional has obtained the necessary skills to configure, maintain, and troubleshoot personal computers, as well as install operating systems and peripheral devices, such as printers. The A+ certification objectives can be integrated into the IT Hardware and System Software course (IS 2002.4) as well as the Operating System (OS) course which is an IS elective. The IS 2002.4 provides students with an exposure to IT hardware and software components and their interaction. Systems components and peripheral devices are identified and studied. The OS software, including I/O drivers and extensions to the OS is studied and utilized in the laboratory. The OS course can be used to integrate and emphasize the OS part of the certification objectives. The A+ has two separate exams: the core exam, which can be taken in the hardware and software course, and the OS exam, which can be taken upon completion of the OS course. Therefore, in order to take the A+ certification students need to enroll in the OS course in addition to the IT hardware and software course. 
Network + is a professional certification established by CompTIA that verifies broad, vendorindependent networking technology skills, such as an understanding of protocols, topologies, networking hardware, and network troubleshooting. Network+ may also be a stepping stone to more advanced certifications. For example, Novell now accepts Network + as a substitute for its Networking Technologies exam for candidates pursuing CNE status. Certified Network + professionals know the layers of the OSI model, can describe features and functions of network components, and have the skills needed to install, configure and troubleshoot basic networking hardware peripherals and protocols. The A+ certification is recommended before taking the Network + certification. The IS 2002.6 (Networks and Telecommunication) course provides an in-depth knowledge of data communications and networking requirements including network and telecommunication technologies, hardware, and software. The Network+ certification domain areas are: media and topologies, protocols and standards, network implementation, and network support. The Network + certification domain areas that can be easily integrated into the IS 2002.6 course are: media and topologies, protocols and standards, and network implementation. The last domain area, network support, can be addressed in an elective network course.

An alternative to the Network+ (Dean, 2005) certification is the Cisco CCNA (Caudle \& Cannon, 2004) certification. The objectives of the Cisco CCNA certification can be covered in one or two Network courses. The Cisco CCNA topics are OSI reference model and layered communications, network protocols, routing, WAN protocols, network management, LAN design, Cisco networking basics, and bridging and switching. Even though the Cisco Networking Academy teaches the CCNA curriculum in four semesters, the certification objectives can be covered in two courses or one course and a lab component. The following topics can be integrated into the IS2002.6: the OSI model, network devices, TCP/IP and IP addressing, network topology and design, WAN concepts, routers and IOS basics, and router start up and configuration. The second network course includes the following topics: routing protocols, IPX/SPX, access lists, PPP and ISDN, frame relay, and switching and VLANs. While Network + is a non proprietary certification, Cisco CCNA requires the use of Cisco products such as routers and switches. Therefore the lab for this course should be equipped with Cisco devices.

Sun developed the Certified Programmer for Java 2 certificate to ensure that the programmer masters specific skills to be productive. The certification topics are: declarations and access control; flow control, assertions and exception handling; garbage collection; language fundamentals; operator assignment; overloading, overriding, runtime type and object orientation; threads; fundamental classes in the java language package; and the collections framework. The integration of one of these certificates (CCNA) into IS 2002.6 course is discussed in the example section.

Table 3: IT certification for integration into IS curriculum

\begin{tabular}{|c|c|c|}
\hline IT CERTIFICATE & CERTIFICATION EXAMS & MATCHING IS COURSES \\
\hline MS MOUS & $\begin{array}{l}\text { Master, Expert or Specialist ex- } \\
\text { ams }\end{array}$ & IS 2002.P0 \\
\hline CompTIA A+ & Core exam, OS exam & $\begin{array}{l}\text { IS2002.4 and one elective Oper- } \\
\text { ating Systems course }\end{array}$ \\
\hline CompTIA Network+ & $\begin{array}{l}\text { One } 2 \text {-hour exam } \\
(\mathrm{A}+\text { is a recommended prerequi- } \\
\text { site })\end{array}$ & $\begin{array}{l}\text { IS } 2002.6 \text { (Networks and Tele- } \\
\text { communication) and one elective } \\
\text { network course }\end{array}$ \\
\hline Cisco CCNA & $\begin{array}{l}\text { One } 90 \text { minute exam } \\
55-65 \text { questions } \\
\text { Passing Score } 849 / 1000\end{array}$ & $\begin{array}{l}\text { IS } 2002.6 \text { (Networks and Tele- } \\
\text { communication) }\end{array}$ \\
\hline
\end{tabular}


Sun Certified Programmer for Java 2
One 2-hour exam (59 multiple choice questions)
IS 2002.5 (Programming and Object Structures)

\section{Example of Integration}

This section shows how to integrate the Cisco CCNA certification into one Network course of the IS curriculum (IS 2002.6). The objectives of the CCNA certification are identified and integrated into the IS course syllabus. The master course syllabus is designed to include both objectives and course outcomes. However, selecting a textbook for the course which covers IS 2002.6 as well as the certification objectives is an issue.

Popular Network textbooks such as Comer (2004) and Tanenbaum (2003) do not cover the CCNA or Network + objectives. Cisco academy teaches four Network courses (each course worth 4 credit hours) CCNA1, CCNA2, CCNA3, and CCNA4. These four courses prepare the students for the CCNA exam. Using the Cisco academy approach requires four semesters of Network courses and many students are not able to go through this process. It is possible to offer one or two courses with a lab component to address the CCNA objectives. Other important Network topics such as network Operating Systems are not required by the CCNA but are required to take the Network + certification exam. Course technology has published a few textbooks to address the CCNA objectives and also textbooks to address the Network + objectives. Instructors who wish to integrate certification objectives into their course could use two textbooks to cover the CCNA objectives and some of the Network + objectives.

\section{CCNA Certification Objectives}

The CCNA certification provides students with critical knowledge and skills necessary to select, connect, configure, and troubleshoot various Cisco networking devices. The certification exam covers topics on extending switched networks with VLANs, determining IP routes, managing IP traffic with access lists, establishing point-to-point connections, and establishing frame relay connections. The CCNA objectives cover four areas, these are:

\section{Planning \& designing}

1.1 Design a simple LAN using Cisco Technology

1.2 Design an IP addressing scheme to meet design requirement

1.3 Select an appropriate routing protocol based on user requirements

1.4 Design a simple internetwork using Cisco Technology

1.5 Develop an access list to meet user specifications

1.6 Choose WAN services to meet customer requirements

\section{Implementation \& operation}

$2.1 \quad$ Configure routing protocols given user requirements

2.2 Configure IP addresses, subnet masks, and gateway addresses on routers and hosts

2.3 Configure a router for additional administrative functionality

2.4 Configure a switch with VLANs and inter-switch communication

2.5 Implement a LAN

2.6 Customize a switch configuration to meet specific network requirements

2.7 Manage system image and device configuration files

2.8 Perform an initial configuration on a switch

2.9 Implement access lists

2.10 Implement simple WAN protocols 


\section{Troubleshooting}

3.1 Utilize the OSI model as a guide for systematic network troubleshooting

3.2 Perform LAN and VLAN troubleshooting

3.3 Troubleshoot routing protocols

3.4 Troubleshoot IP addressing and host configuration

3.5 Troubleshoot a device as part of a working network

3.6 Troubleshoot an access list

3.7 Perform simple WAN troubleshooting

\section{Technology}

4.1 Describe network communications using layered models

4.2 Describe the spanning Tree process

4.3 Compare and contrast key characteristics of LAN environments

4.4 Evaluate the characteristics of routing protocols

4.5 Evaluate TCP/IP communication process and its associated protocols

4.6 Describe the components of network devices

4.7 Evaluate rules for packet control

4.8 Evaluate key characteristics of WANs

\section{Cisco CCNA versus CompTIA Network+}

The following section provides a brief comparison between Cisco CCNA and CompTIA Network + certifications. The first part of the CCNA and Network+ curriculum is very similar. They both cover the basic concepts of networks, such as the OSI model, transmission basics and network media, network protocols, networking hardware, topologies and access methods, WANs and remote connections, and TCP/IP protocol suites. The second parts of the curriculum diverge. While the CCNA concentrates on the router and switch configuration using Cisco IOS, Network+ concentrates on configuring small LANs using different operating systems such as Windows 2003 server, Linux, Novel Netware, and Apple Talk. In the lab, the main difference is that CCNA requires Cisco equipment, specifically routers and switches, in order for students to fully understand the course. There is also emulation software which can help the students understand part of Cisco Internetwork Operating Systems (IOS); however the availability of the equipments is vital to fully understand the materials. On the other hand, the Network+ certificate requires a few personal computers with different network operating systems such as Windows 2003 Server, Linux, Apple Talk, and Novel Netware. The last difference is the IT certification exam passing score. While CCNA current passing score is $849 / 1000$, the Network+ current passing score is 554/900. Finally, it is important to emphasize that both the CCNA and Network+ certification require spending a substantial amount of time in the lab in order to pass the exam.

\section{Master course syllabus}

This proposed master course syllabus is designed to achieve the course objectives as well as prepare students to take the CCNA certification exam. The master syllabus is designed for a fourcredit hour course to allow instructors the flexibility to include detailed coverage of the certification objectives as needed. The three exams are designed to verify comprehension of Network concepts. The course assessment is designed to cover both comprehension of the course material and the certification objectives. The assessment is optimized by assigning $50 \%$ of the final grade to the course work and $50 \%$ to the certification exams. Obtaining a passing grade in the course is necessary but not a sufficient condition to pass the certification exam. 


\section{Computer Network \& Communication I}

\section{Credit hours: 5 \\ Course Description:}

This course introduces a comprehensive background in networking concepts. The course also covers all the objectives of CCNA allowing students to take the certification exam upon completion of the course.

Textbook: CCNA Guide to Cisco Networking, $3^{\text {rd }}$ edition

Author: Kelly Caudle and Kelly Cannon

Publisher: Course Technology, 2004

Reference: Network + Guide to Networks, $4^{\text {th }}$ edition

Author: Tamara Dean

Publisher: Course Technology, 2005

\section{Course Objectives:}

To understand the seven layers of the OSI reference model

To understand network segmentation using bridges, switches, routers, and gateway.

To understand the TCP/IP protocols and the advanced routing concepts

To understand the various network architecture models and various types of network media

To understand WAN standard, connection methods, protocols, and WAN connection methods

To understand routers and IOS basics

To understand router startup and configuration

To understand routing protocols and NAT

To understand advanced routing protocols

To understand access lists, extended access lists and how to apply them to interfaces

To understand PPP and ISDN and how to configure ISDN

To understand Frame Relay standards and equipment

To understand Switching and VLANs

Evaluation Procedures:

$\begin{array}{ll}\text { Three Tests (closed book) } & 20 \%\end{array}$

Lab Projects and Case Study $\quad 30 \%$

CCNA Certification Exam $\quad 50 \%$

Course Topics and Certification Objectives

\begin{tabular}{|c|l|l|l|}
$\begin{array}{c}\text { Week/ } \\
\text { Period }\end{array}$ & \multicolumn{1}{|c|}{ Course Topics } & \multicolumn{1}{|c|}{$\begin{array}{c}\text { Book/ } \\
\text { Chapter }\end{array}$} & $\begin{array}{c}\text { Certif. } \\
\text { Object. }\end{array}$ \\
\hline 1.1 & Introducing Networks, Network terminology & Ch.1 & $3.1,4.1$ \\
1.2 & Understanding the OSI Model & & \\
1.3 & Connection-Oriented Versus Connectionless, Data encapsulation & Ch.1 Lab & \\
1.4 & Lab \#1 Introducing Networks & Ch.2 & $3.2,4.6$ \\
\hline 2.1 & Network devices, Repeaters, Hubs, Wireless Access Points & & \\
2.2 & Network Segmentation, Bridges, Types of Bridges, Switches & & \\
2.3 & Routers, Physical vs. Logical Addresses, Brouters, Gateways & Ch.2 Lab & \\
2.4 & Lab \#2 Network Devices & & \\
\hline & & & \\
\hline
\end{tabular}




\begin{tabular}{|c|c|c|c|}
\hline $\begin{array}{l}3.1 \\
3.2 \\
3.3 \\
3.4\end{array}$ & $\begin{array}{l}\text { TCP/IP and IP Addressing, TCP/IP Protocol Suite } \\
\text { ARP, RARP, ARP Tables, Ping and Trace Utilities } \\
\text { IP Addressing, MAC to IP Address Translation, IP Classes } \\
\text { Lab \# } 3 \text { TCP/IP and IP Addressing }\end{array}$ & Ch.3 Lab & $\begin{array}{l}1.2,3.4 \\
4.5\end{array}$ \\
\hline $\begin{array}{l}4.1 \\
4.2 \\
4.3 \\
4.4\end{array}$ & $\begin{array}{l}\text { Subnet Addressing, Broadcast Address, Subdividing IP Classes } \\
\text { Subnet Masking, CIDR, Summarization } \\
\text { Variable Length Subnet Masks, Understanding Packet Transm. } \\
\text { Lab \# } 4 \text { Network Topology and Design }\end{array}$ & $\begin{array}{l}\text { Ch.3 } \\
\text { Ch.3 } \\
\text { Ch.3 Lab }\end{array}$ & 4.5 \\
\hline $\begin{array}{l}5.1 \\
5.2 \\
5.3 \\
5.4\end{array}$ & $\begin{array}{l}\text { Network Topology and Design: Physical Topologies } \\
\text { Network Architecture } \\
\text { Media, Horizontal Cabling Standards } \\
\text { Lab \# } 5\end{array}$ & Ch.4 Lab & $\begin{array}{l}1.1,1.4 \\
2.5,3.5\end{array}$ \\
\hline $\begin{array}{l}6.1 \\
6.2 \\
6.3 \\
6.4\end{array}$ & $\begin{array}{l}\text { Performance Considerations } \\
\text { Testing Cable } \\
\text { LAN Design Models, Network-Management Tools } \\
\text { Test \# } 1\end{array}$ & Ch.4 & 4.3 \\
\hline $\begin{array}{l}7.1 \\
7.2 \\
7.3 \\
7.4\end{array}$ & $\begin{array}{l}\text { WAN Concepts: WAN Connection Methods, WAN DLC } \\
\text { WAN Physical Layer } \\
\text { WAN Topologies } \\
\text { Lab \# } 6 \text { WAN Concepts }\end{array}$ & Ch.5 Lab & $\begin{array}{l}1.6,3.5 \\
4.8\end{array}$ \\
\hline $\begin{array}{l}8.1 \\
8.2 \\
8.3 \\
8.4\end{array}$ & $\begin{array}{l}\text { Router and IOS Basics: Cisco Router User Interface } \\
\text { Router Configuration Modes } \\
\text { Switch User Interface } \\
\text { Lab \# } 7 \text { Router and IOS Basics }\end{array}$ & Ch.6 Lab & $\begin{array}{l}2.3,2.7 \\
2.8\end{array}$ \\
\hline $\begin{array}{l}9.1 \\
9.2 \\
9.3 \\
9.4\end{array}$ & $\begin{array}{l}\text { Router Startup and Configuration: Router Startup } \\
\text { Router Configuration Files } \\
\text { IP Connectivity } \\
\text { Lab \# } 8 \text { Router Startup and Configuration }\end{array}$ & Ch.7 Lab & $\begin{array}{l}2.2,2.3 \\
2.7,2.8\end{array}$ \\
\hline $\begin{array}{l}10.1 \\
10.2 \\
10.3 \\
10.4\end{array}$ & $\begin{array}{l}\text { Routing Protocols and Network Address Translation: NAT } \\
\text { Configuring Network Address Translation } \\
\text { Routing Information Protocol, Static Routing } \\
\text { Lab \# } 9 \text { Routing Protocols and Network Address Translation }\end{array}$ & Ch.8 Lab & $\begin{array}{l}1.3,2.1 \\
3.3,3.4\end{array}$ \\
\hline $\begin{array}{l}11.1 \\
11.2 \\
11.3 \\
11.4\end{array}$ & $\begin{array}{l}\text { Advanced Routing Protocols: Classful and Classless R.P. } \\
\text { RIP Version 2, EIGRP, OSPF } \\
\text { OSPF Concepts \& Operation } \\
\text { Lab \# } 10 \text { Advanced Routing Protocols + Test \# } 2\end{array}$ & Ch.9 Lab & $1.3,2.1$ \\
\hline
\end{tabular}




\begin{tabular}{|c|l|l|l|}
\hline 12.1 & Access Lists: Usage and Rules, Standard IP Access Lists & Ch.10 & $1.5,2.10$ \\
12.2 & Standard IP Access List Examples & & $3.6,4.7$ \\
12.3 & Extended IP Access Lists, Using Named Lists & Ch.10 Lab & \\
12.4 & Lab \# 11 Access Lists & Ch.11 & $2.11,3.7$ \\
\hline 13.1 & PPP and ISDN: PPP & & \\
13.2 & ISDN Operations & & \\
13.3 & ISDN BRI Configuration Examples & Ch.11 Lab & \\
13.4 & Lab \# 12 PPP and ISDN & Ch.12 & $2.11,3.7$ \\
\hline 14.1 & Frame Relay: Frame Relay Standards and Equipment & & \\
14.2 & Virtual Circuits, LMI, Performance Parameters & & \\
14.3 & Frame Relay Topologies and Configuration & Ch.12 Lab & \\
14.4 & Lab \# 13 Frame Relay & Ch.13 & $1.1,1.4$ \\
\hline 15.1 & Switching and VLANs: Ethernet Operations & & $2.4,2.6$ \\
15.2 & LAN Segmentation, LAN Switching & & $2.9,3.2$ \\
15.3 & Virtual LANs & Ch.13 Lab & 4.2 \\
\hline 15.4 & Lab \# 14 Switching and VLANs + Test \# 3 & & \\
\hline 16.1 & CCNA Exam with Prometric Testing Center & \\
\hline
\end{tabular}

\section{Conclusions}

In this paper, a comprehensive approach to develop IS curricula based on ABET requirements and IS 2002 is introduced. Moreover, to address government and industry needs, the proposed curriculum includes IT certification tracks. The curriculum includes courses in general education, core IS courses, IS electives, environmental requirements, analytical and statistical requirements, and general electives. IS components that have the potential to lead to certification are identified and integrated in the model curriculum. The proposed model curriculum provides a framework to integrate certification modules in IS courses at various levels of the curriculum.

An example that shows how to integrate a Network certification, Cisco CCNA, is presented. A brief comparison between Cisco CCNA and CompTIA Network+ is provided to show the lab requirement for each certification. A master course syllabus is developed to show coverage of the CCNA objectives. The syllabus also provides some suggestions on textbook selection.

It is anticipated that universities and colleges will benefit from this study by using the model curriculum as a basis to tailor their own curricula in order to address their particular needs. Furthermore, the proposed model curriculum will enable universities and colleges world wide to develop and maintain academic programs that are based on the common body of knowledge of the IS field and be consistent both with regional and international employment needs. 


\section{References}

Benander, A., Benander, B., \& Sang, J. (2004). Factors related to the difficulty of learning to program in Java - an empirical study of non-novice programmers. Information and Software Technology, 46, 99107. Retrieved May 10, 2005 from http://www.ElsevierComputerScience.com

Caudle, K. \& Cannon, K. (2004). CCNA guide to Cisco networking ( $3^{\text {rd }}$ ed.). Course Technology. [See http://www.course.com for description.]

Comer, D. (2004). Computer networks and internets (4th ed.). Prentice Hall. [Table of contents available at http://netbook.cs.purdue.edu/toc/toc00.htm]

Computing Accreditation Commission. (2004). Criteria for Accrediting Computing Programs. Retrieved May $10^{\text {th }}, 2005$ from http://www.abet.org/criteria_cac.html

Dean, T. (2005). Network+ guide to networks ( $4^{\text {th }}$ ed.). Course Technology. [See http://www.course.com for description.]

Denning, J. (2001). The IT schools movement. Communications of the ACM, 44(8), 19-22. Retrieved May 10, 2005 from http://portal.acm.org/citation.cfm?doid=381641.381649

Gorgone, J., Davis, G., Valacich, J., Topi, H., Feinstein, D., \& Longenecker, H. (2002). IS 2002: Model curriculum and guidelines for undergraduate programs in information systems. Retrieved May 10, 2005 from http://www.acm.org/education/is2002.pdf

Houston, S., Blesse, S., \& Herrod, C. (2005). Integration of the Cisco Networking Academy at a four-year university. Proceedings of the 2005 American Society for Engineering Education Annual Conference \& Exposition, Portland, OR, June 13-15.

Lidtke, D., \& Yaverbaum, G. (2003). Developing accreditation for information systems education. IT Professionals, January/February, 41-45.

Lunt. B., Lawson, E., Goodman, G., \& Helps, R. (2002). Designing an IT curriculum: The results of the first CITC conference. Proceedings of the 2002 American Society for Engineering Education Annual Conference \& Exposition. Retrieved May 10, 2005 from http://asee.org/acPapers/2002-1626_Final.pdf

Mehic, N., \& Al-Soufi, A. (1999). Updating the CS curriculum: Traditional vs. market-driven approaches. Informing Science, 1(4), 69-73. Retrieved May 10, 2005 from http://www.inform.nu/Articles/Vol1/v1n4p69-73.pdf

Reichgelt, H., Lunt. B, Ashford, T., Phelps, A., Slazinski, E., \& Willis, C. (2004). A comparison of baccalaureate programs in information technology with baccalaureate programs in computer science and information systems. Journal of Information Technology Education, 3, 19-34. Retrieved May 10, 2005 from http://www.jite.org/documents/Vol3/v3p019-034-098.pdf

Reichgelt, H., Zhang, A., \& Price, B. (2002). Designing an information technology curriculum: The Georgia Southern University experience. Journal of Information Technology Education, 1(4), 213-221. Retrieved May 10, 2005, from http://www.jite.org/documents/Vol1/v1n4p213-221.pdf

Tanenbaum, A. (2003). Computer networks ( $4^{\text {th }}$ ed.). Prentice Hall. [Description available at http://vig.prenhall.com/catalog/academic/product/0,1144,0130661023,00.html]

Tucker, A., Deek, F., Jones, J., McCowan, D., Stephenson, C., \& Verno, A. (2003). A model curriculum for K-12 computer science: Final report of the ACM K-12 Education Task Force Curriculum Committee. Retrieved from http://www.isp.org.pl/podstawa/podstawa_files/K12_Computer_Science.pdf

Zeng, F. (2004). A new approach to integrate computer technology certification into computer information system programs, 2004 Annual ASEE Conference, Salt Lake City, Utah, Session 2558. Retrieved May 10, 2005 from http://asee.org/acPapers/2004-1708_Final.pdf 


\section{Appendix A: IS Core Programming Course Description}

\begin{tabular}{|c|c|}
\hline $\begin{array}{l}\text { COURSE } \\
\text { TITLE }\end{array}$ & COURSE DESCRIPTION/OBJECTIVES \\
\hline $\begin{array}{l}\text { Object Oriented } \\
\text { Programming }\end{array}$ & $\begin{array}{l}\text { Program design and development using Java. A disciplined approach to problem solv- } \\
\text { ing and algorithm is stressed through out the course. Topics include syntax and seman- } \\
\text { tics, input/output, selection, iterative construct, data type, classes, methods, inheri- } \\
\text { tance, overloading, overriding, and arrays. After completing this course, you will } \\
\text { know how to: } \\
\text { - Describe the basic of object-oriented programming concepts, the Java } \\
\text { platform, and types of Java programs, as well as how to install and con- } \\
\text { figure the Java SDK. } \\
\text { - Use constants, variables, and various data types. } \\
\text { - Create and use methods, classes, and instantiate objects from classes. } \\
\text { - Define blocks and scope of variable, overload method and constructors, } \\
\text { and work with constants. } \\
\text { - Accept keyboard input, use the JOptionPane class, draw flowcharts and } \\
\text { make decisions by using if...else and switch statements, use AND, OR, } \\
\text { conditional, and NOT operators, and their order of precedence. } \\
\text { - Use while loops, do...while loops, shortcut arithmetic operators, for loops } \\
\text { and, nested loops. } \\
\text { - Manipulate characters and use Strings methods and the StringBuffer class } \\
\text { - Declare, initialize an array, declare and create an array of objects, and } \\
\text { - Parch an array. } \\
\text { - Iays, and create two-dimensional and multidimensional arrays. } \\
\text { Implement inheritance and extend classes, override superclass methods, and } \\
\text { - } \text { use information hiding and protection. } \\
\text { - Treate abstract classes and use dynamic method binding, create an array of } \\
\text { objects, compare objects, and create interfaces and packages. } \\
\text { ate your own exceptions. } \\
\text { - Create HTML documents to run applet containing AWT components and cre- } \\
\text { ate applets with Swing components. }\end{array}$ \\
\hline $\begin{array}{l}\text { Web } \\
\text { Programming }\end{array}$ & $\begin{array}{l}\text { This course examines the technical, application, and enterprise layers of Web-based } \\
\text { systems. Technical aspects include the technologies and principles of Web site opera- } \\
\text { tion and management. Topics in the application layer include Web document design, } \\
\text { and development practices and standards. At the enterprise level, E-business models, } \\
\text { electronic transactions, and social, legal, and ethical issues are addressed. The course } \\
\text { introduces the principles of control structures, object-based programming and various } \\
\text { markup languages (HTML, DHTML and XML) and scripting languages (JavaScript, } \\
\text { VBScript and Perl). This course is distinguished by its focus on Web-based application } \\
\text { development and its emphasis in server-side treatment. It also covers client/server sys- } \\
\text { tems and connections to databases. }\end{array}$ \\
\hline
\end{tabular}

\section{Appendix B: Proposed IS Model Curriculum}

\begin{tabular}{|l|ll|}
\hline AREA OF STUDY & & \multicolumn{1}{c|}{ COURSE NAME } \\
\hline Basic Studies & $\bullet$ & Introduction to Computer Information Systems (3) \\
$(12 \mathrm{cr})$ & $\bullet$ & Introduction to Speech (3) \\
& $\bullet$ & English Composition II (3) \\
& $\bullet$ & College Algebra or Stat. I or Calculus \& Analytic Geometry (3) \\
\hline
\end{tabular}




\begin{tabular}{|c|c|}
\hline $\begin{array}{l}\text { Introductory } \\
\text { Studies } \\
(24 \mathrm{cr})\end{array}$ & $\begin{array}{l}\text { - Arts and Humanities (6) } \\
\text { Art Appreciation, Communication (recommended for IS students), Language, } \\
\text { Literature, Philosophy (recommended for IS students), Religious studies } \\
\text { - Natural Sciences and Mathematics (9) } \\
\text { Astronomy, Biology, Chemistry, Geology, Mathematics (recommended for } \\
\text { IS students), Statistics (recommended for IS students), Physics } \\
\text { - Social and Behavioral Sciences (9) } \\
\text { Economics (micro and macro, recommended for IS students), Geography, } \\
\text { Political Science, Psychology, Sociology }\end{array}$ \\
\hline $\begin{array}{l}\text { Ethics } \\
(3 \mathrm{cr})\end{array}$ & - Either a course in philosophy or an approved college ethics course \\
\hline $\begin{array}{l}\text { IS Core Courses } \\
(33 \mathrm{cr})\end{array}$ & $\begin{array}{ll}\text { - } & \text { Personal Computer Productivity Tools (3) } \\
\text { - } & \text { Introduction to Computer Information Systems (3) } \\
\text { - } & \text { Web Programming (3) } \\
\text { - } & \text { IT Hardware and Software (3) } \\
\text { - } & \text { Object Oriented Programming (3) } \\
\text { - } & \text { Advanced Object Oriented Programming (3) } \\
\text { - } & \text { Networks and Data Communications (3) } \\
\text { - } & \text { Database Systems (3) } \\
\text { - } & \text { Algorithms and Data Structures (3) } \\
\text { - } & \text { Project Management (3) }\end{array}$ \\
\hline $\begin{array}{l}\text { IS Environment } \\
(15 \mathrm{cr})\end{array}$ & $\begin{array}{ll} & \text { Financial Accounting (3) } \\
- & \text { Principles of Economics I (Micro) (3), GE } \\
\text { - } & \text { Principles of Economics II (Macro) (3), GE } \\
\text { - } & \text { Financial Management (3) } \\
& \text { Organizational Behavior (3) }\end{array}$ \\
\hline $\begin{array}{l}\text { Quantitative } \\
\text { Analysis }(9 \mathrm{cr})\end{array}$ & $\begin{array}{ll}\text { - } & \text { Statistics I (3), GE } \\
\text { - } & \text { Discrete mathematics (3) } \\
\text { - } & \text { Statistics II (3) }\end{array}$ \\
\hline $\begin{array}{l}\text { IS Electives } \\
(18 \mathrm{cr})\end{array}$ & $\begin{array}{ll}\text { - } & \text { Introduction to COBOL Programming } \\
\text { - } & \text { Introduction to Visual Basic.NET Programming } \\
\text { - } & \text { Object Oriented Analysis and Design } \\
\text { - } & \text { Operating Systems } \\
\text { - } & \text { Multimedia Systems } \\
\text { - } & \text { Web Management } \\
\text { - } & \text { Internship } \\
\text { - } & \text { Computer Systems \& Assembly Language } \\
\text { - } & \text { E-business \& E-commerce } \\
\text { - } & \text { Capstone Experience }\end{array}$ \\
\hline $\begin{array}{l}\text { General Electives } \\
(15 \mathrm{cr})\end{array}$ & $\begin{array}{ll}- & \text { Microeconomics (GE) } \\
\text { - } & \text { Accounting I (Financial) } \\
\text { - } & \text { Accounting II (Managerial) } \\
\text { - } & \text { Business Finance } \\
\text { - } & \text { Orinciples of Marketing } \\
\text { - } & \text { General Psychology }\end{array}$ \\
\hline
\end{tabular}




\section{Biographies}

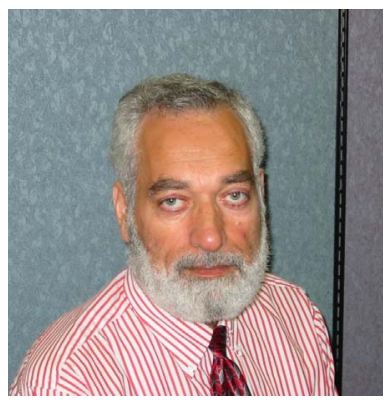

Akram Aj-Rawi is a Professor of CIS at Zayed University, UAE. He has worked at several academic institutions of which the last two were the University of Missouri-Columbia and Columbia College, MO. His teaching interests include programming languages, logic design, and computer architecture. His research interests include computer simulation, web-caching architecture, and curriculum design. He holds certifications in A+, Network+, Sun Certified Java Programmer, ICDL, and CCNA Intro.

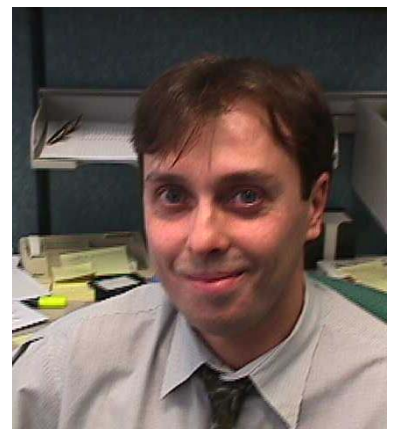

Azzedine Lansari received a $\mathrm{PhD}$ in Biomedical Engineering from North Carolina State University in 1992. From 1992-1998, he was a senior researcher at MANTECH, NC. He joined Zayed University in August 1998. Currently he is an assistant professor of Information systems. His research interests include systems modeling, educational technology and curriculum design in Information Systems. His teaching interests include instructional technology and statistical modeling.

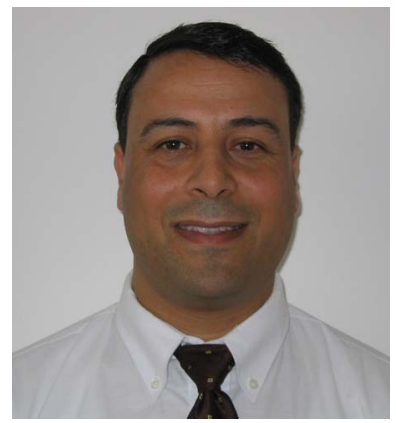

Faouzi Bouslama received a $\mathrm{PhD}$ in Electronics Engineering from Shizuoka University, Japan, in 1992. From 1992-1994, he was a researcher at Toshiba Co., Tokyo. From 1994-2000, he was Associate Professor of Information Systems, Hiroshima City University, Japan. He joined Zayed University, UAE, in August 2000. Currently, he is a Professor of Information Systems, Zayed University, UAE. His research interests include Neuro-fuzzy modeling and control, Signal processing, and IS curriculum design and development. 